\title{
Comparative International Entrepreneurship: Theoretical Framework and Research Development
}

\author{
Agnieszka Głodowska
}

\section{A B S T R A C T}

Objective: The aim of the article is to recognise the scientific identity of comparative international entrepreneurship ( $\mathrm{CIE}$ ) and to review the literature on this problem in the perspective of international entrepreneurship (IE).

Research Design \& Methods: The applied research method is the analysis of theoretical and empirical articles on comparative international entrepreneurship published in the years 1989-2018. On this basis, the Author formulates propositions of problems suitable for the scientific exploration in the future in the stream of comparative research.

Findings: Comparative international entrepreneurship is one of three research domains of international entrepreneurship. We can identify here a few important problems for future research, which concern institutional and cultural conditionings of entrepreneurship, the operationalisation of entrepreneurship and the assessment of the effects of entrepreneurship for the economic growth and development.

Implications \& Recommendations: It is recommended to conduct theoretical and empirical in-depth research into international entrepreneurship in the comparative approach. It is of great cognitive importance for the development of the discipline and of utilitarian importance both for entrepreneurs - the micro level and economic decisionmakers - the macro level.

Contribution \& Value Added: The article fills a research gap related to the conceptual embedment of comparative international entrepreneurship and is one of the first articles to review the literature concerning this problem.

\begin{tabular}{ll}
\hline Article type: & conceptual article \\
& comparative international entrepreneurship; international entrepre- \\
Keywords: & neurship; comparative research; international comparison; entrepre- \\
& neurial internationalisation
\end{tabular}

JEL codes: $\quad$ L26, O57, P52

Received: 13 January $2019 \quad$ Revised: 24 March $2019 \quad$ Accepted: 12 April2019

\section{Suggested citation:}

Głodowska, A. (2019). Comparative International Entrepreneurship: Theoretical Framework and Research Development. Entrepreneurial Business and Economics Review, 7(2), 235-248. https://doi.org/10.15678/EBER.2019.070213 


\section{INTRODUCTION}

Comparative international entrepreneurship (CIE) is one of three research domains of international entrepreneurship (IE), in addition to entrepreneurial internationalisation and comparisons of entrepreneurial internationalisation. International entrepreneurship is a relatively new research area which was initiated by the end of 1980 s, and its real development took place a decade later (Wach, 2018). It is understood as discovering, enacting, assessing and using opportunities beyond state borders in order to create future goods and services. International entrepreneurship includes both research into entrepreneurship in the sense of internationalisation and international comparisons of domestic entrepreneurship in many countries (McDougall \& Oviatt, 2005). The problem most often discussed in its stream is entrepreneurial internationalisation (McDougall \& Oviat, 1994; Jones \& Coviello, 2004; Cavusgil \& Knight, 2015; Autio, 2018). International entrepreneurship is mainly associated with the internationalisation process. The other two research areas: comparative international entrepreneurship and comparisons of entrepreneurial internationalisation are less recognized or completely disregarded in international literature. On the other hand, growing interest in domestic entrepreneurship has been visible for a few years (Coviello, McDougall, \& Oviatt, 2011 Beynon, Jones, \& Pickernell, 2018), which may be the contribution to the development of international research in this direction. Therefore, conceptual embedment of this type of research in theory, as well as the summary of the existing output are worth considering. The validity of combining comparative research and international entrepreneurship was already articulated in its first definitions (McDougall \& Oviatt, 2000; 2003; 2005).

The aim of the article is to recognise the affinity and scientific identity of the comparisons of international entrepreneurship and to make the systematic literature review in this area. Through the realisation of the aim thus defined it is possible to formulate propositions of problems recommended for the development of comparative research into international entrepreneurship. Due to the character of the article, research methods applied in the work are the analysis of the content of theoretical and empirical publications in the area of international entrepreneurship in the years 1989-2018.

The article is divided into interrelated sections. First section describes the applied research methods, the scope of research and sources of information. Second section presents the review of literature, based on which thematic areas for further research were identified. In the third section a discussion is conducted on the indicated research areas.

\section{MATERIAL AND METHODS}

The aim of the article is the recognition of the scientific identity and conceptual embedment in research problems of comparative international entrepreneurship. Moreover, the article attempts to sum up the existing scientific output in comparative research on international entrepreneurship. The approach provides a firm theoretical framework for future research into comparative entrepreneurship in the comparative approach, through proposing research problems which can be developed in future empirical studies. The main research method used in the article is a critical analysis of literature on international entrepreneurship and its synthesis. In the first place, the scientific affinity of comparative 
international entrepreneurship is recognized. Then, attention is paid to the scientific identity of this research area. In the next part of the article there is a literature review in the search for an answer to the question about the theoretical bases of international comparative research into entrepreneurship. Finally, the quantitative and qualitative analysis of the existing output on comparative international entrepreneurship is conducted.

The bibliometric analysis was conducted based on renowned, international bases of publishers: Emerald Insight, Jstor, Science Direct, Springer, Willey Online Library. In addition, the abstract and citation base Scopus was used. The choice of the above sources arose from their position in international rankings of such centres as: Australian Political Studies Association (APSA), Socio - Economic and Natural Sciences of the Environment (SENSE), Centre for Resource Studies for Human Development (CERES). The adopted period for the analysis are the years 1989-2018. The adoption of this research period resulted from two assumptions: 1) the assumption concerns the year 1989, which is related to the period of the initiation of research into international entrepreneurship. It was then when the ground-breaking publication by McDougall (1989) on domestic and international ventures was published 2) the assumption concerns the year 2018, which was chosen as the final year to present the most current state of knowledge on international entrepreneurship in the comparative approach.

\section{LITERATURE REVIEW AND THEORY DEVELOPMENT}

\section{The Affiliation and Scientific Identity of Comparative International Entrepreneurship}

Comparative international entrepreneurship belongs to the stream of research into international entrepreneurship. International entrepreneurship is a relatively young research area, developed within research combining entrepreneurship and international business (Wach, 2018). According to McDougall and Oviatt (1994), Knight and Cavusgil (2004), and Perényi and Lansocz (2018), it can aspire to be called an independent scientific discipline. According to the first definitions, international entrepreneurship is understood as the development of new ventures or start-ups which from the very beginning engage in international activity and thus perceive their international activities from their inception (McDougall, 1989). In the course of deepening the research into international entrepreneurship, the Author reviewed her conceptual approach indicating that in addition to innovative, proactive and risky behaviours, research into international entrepreneurship includes also comparative research into entrepreneurial behaviours in numerous countries, thus emphasizing the comparative dimension in the perspective of international entrepreneurship (McDougall \& Oviatt, 2000). The final legitimisation of comparative research within international entrepreneurship was made by Jones, Coviello and Tang (2011), who, based on 232 scientific publications, made the typisation of the research areas of international entrepreneurship mentioning three research domains defined as research types:

- Type A: Entrepreneurial internationalisation.

- Type B: International comparisons of entrepreneurship (countries and cultures).

- Type C: Comparative entrepreneurial internationalisation.

According to Table 1, we can identify comparative research within international entrepreneurship research in two ways. Firstly, we can indicate that there are two fundamental research problems in entrepreneurship: 1) internationalisation, 2) comparative 
research. Then, we can divide comparative research into comparative research on domestic entrepreneurship and comparative research on entrepreneurial internationalisation. Secondly, each of these subjects can be indicated separately, namely: 1) entrepreneurial internationalisation, 2) comparative research on entrepreneurship, 3) comparative research on entrepreneurial internationalisation.

Table 1. Research domains of international entrepreneurship according to Jones, Coviello and Tang (2011)

\begin{tabular}{|c|c|c|}
\hline Type & Domain & Research problems \\
\hline $\begin{array}{l}\varangle \\
\stackrel{2}{2} \\
\stackrel{2}{2}\end{array}$ & Entrepreneurial Internationalisation & $\begin{array}{l}\text { - Venture type } \\
\text { - Internationalisation } \\
\text { - Networks \& Social Capital } \\
\text { - Organisational Issues } \\
\text { - Entrepreneurship } \\
\end{array}$ \\
\hline $\begin{array}{l}\infty \\
\stackrel{\infty}{2} \\
\stackrel{2}{2}\end{array}$ & $\begin{array}{l}\text { International Comparisons } \\
\text { of Entrepreneurship }\end{array}$ & $\begin{array}{l}\text { - Cross-country Research } \\
\text { - Cross-culture Research } \\
\text { - Combined Cross-country \& Cross-culture }\end{array}$ \\
\hline $\begin{array}{l}u \\
\stackrel{0}{2} \\
\stackrel{2}{2}\end{array}$ & $\begin{array}{l}\text { Comparative Entrepreneurial } \\
\text { Internationalisation }\end{array}$ & $\begin{array}{l}\text { - Venture Type } \\
\text { - Internationalisation Patterns \& Process } \\
\text { - Internationalisation Influences } \\
\text { - Organisational Issues }\end{array}$ \\
\hline
\end{tabular}

Source: adopted from Jones, Coviello and Tang (2011, p. 636).

Chronologically, it is claimed that the first research area of international entrepreneurship was internationalisation, then international comparisons of entrepreneurship and comparative entrepreneurial internationalisation (Jones, Coviello, \& Tanga, 2011; Allen, 2016; Hofman-Kohlmeyer, 2018). In the years 1989-1996, the main subject of research was entrepreneurial internationalisation, and first of all the explanation why, when and how firms engage in international business. From 1990, research into comparative international entrepreneurship was initiated. It concerned the assessment of the entrepreneurship level in different countries, cultural differences, or combining the indicated issues. This research area developed especially till 2002. Then, from 2001 attention was paid to comparing the internationalisation process in different countries. It basically concerned types of international ventures and internationalisation patterns (Jones, Coviello, \& Tanga, 2011; Allen, 2016; Hofman-Kohlmeyer, 2018).

The scientific identification of comparative research on international entrepreneurship is strictly related to determining the legitimisation of the scientific independence of international entrepreneurship itself. There is no consistent approach to it. Doubts concerning the scientific identity of international entrepreneurship arise from the fragmentary character and the inconsistent application of terms, concepts, paradigms and theoretical constructs (Keupp \& Gassman, 2009). Moreover, Coviello and Jones (2004) question the methodology of research in this stream. There is no balance between exploratory and explicative studies. It all points to scientific immaturity of international entrepreneurship. On the other hand, in recent years a very dynamic development of research into international entrepreneurship has been visible, which brought about the occurrence of scientific journals strictly related to this research domain. A great number of publications, monographs come out. International 
conferences are organised, and majors with its name are introduced at universities. It all indicates the delimitation between international entrepreneurship and other scientific disciplines, thus meaning its scientific independence. There are also premises enabling to question the accusation of the lack of theoretical bases identifying international entrepreneurship. International entrepreneurship derives from the internationalisation theory (Kraśnicka, 2012; Wach, 2018), however, distinguishing entrepreneurial internationalisation from other internationalisation forms arises from the cognitive approach (Jones \& Coviello, 2004; Etemad, 2018). Moreover, the contribution of entrepreneurship, and, to be more exact, classical and neoclassical concepts of entrepreneurship discussed in economics, the Austrian school and entrepreneurial orientation is also important. Within international entrepreneurship entrepreneurial mechanisms arising from entrepreneurship theory are discussed at the international level, therefore the scope changes from the domestic to the international one (Daszkiewicz, 2014). Theoretical bases for international entrepreneurship create the conceptual framework for comparative research. The institutional approach is of special significance here, and it is considered in the majority of papers on international entrepreneurship (Zucchella \& Magniani, 2016). Moreover, the theoretical framework for comparative research into entrepreneurship set international business concepts, e.g. transaction cost theory (Brouthers \& Nakos, 2004). Also, we cannot skip the resource-based theory and economic entrepreneurship concepts (van Stel, Carree, \& Thurik, 2005).

From those two different perspectives of perceiving international entrepreneurship in the scientific space the need for an interdisciplinary but holistic approach to the theoretical framework and the methodology of research into international entrepreneurship arises, which should be treated as a natural process of the formation of a new scientific discipline (Jones \& Coviello, 2011).

Proposition 1: Comparative international entrepreneurship should be developed as one of research domains of international entrepreneurship, which is at the stage of formation as an independent scientific discipline.

\section{Comparative International Entrepreneurship in Prior Research}

The analysis of the existing output on international comparisons of entrepreneurship boils down to the search for papers according to the adopted key words 'comparative international entrepreneurship'. In the first place, the bibliometric analysis was presented, and then the analysis of the content was made. The results of the search for publications in the bases of publishers according to the applied key words were similar: Emerald Insight $(n=7,338)$, Jstor $(n=4,784)$, Science Direct $(n=5,252)$, Springer $(n=14,521)$, Willey Online Library $(n=14,803)$. The biggest number of publications on international comparisons of entrepreneurship was published by Springer and Wiley Online Library. In total, in the period of the analysed almost 30 years 30 thousand publications were identified which included the key words 'Comparative international entrepreneurship'. We should remember that the statistics include a great variety of scientific disciplines and research areas. Every publisher autonomously defines the thematic scope and nomenclature, therefore, the identification is not identical: Emerald Insight (strategic management, entrepreneurship, education, human resources, international business, economics), Jstor (business, economics, management and organisational behaviours, developmental research), Springer (business and management, 
economics, international relations, political relations, education), Wiley Online Library (management and business, economics, developmental research, accounting).

Based on the number of the publications brought out, the real development of comparative research on entrepreneurship has been visible since 2005. Therefore, we can claim that it is a very young research area, in fact developing for a few years. It is a problem relatively poorly recognized in economic literature, as well as the literature on entrepreneurship and international business (Figure 1). In the Polish literature the subject is practically absent.

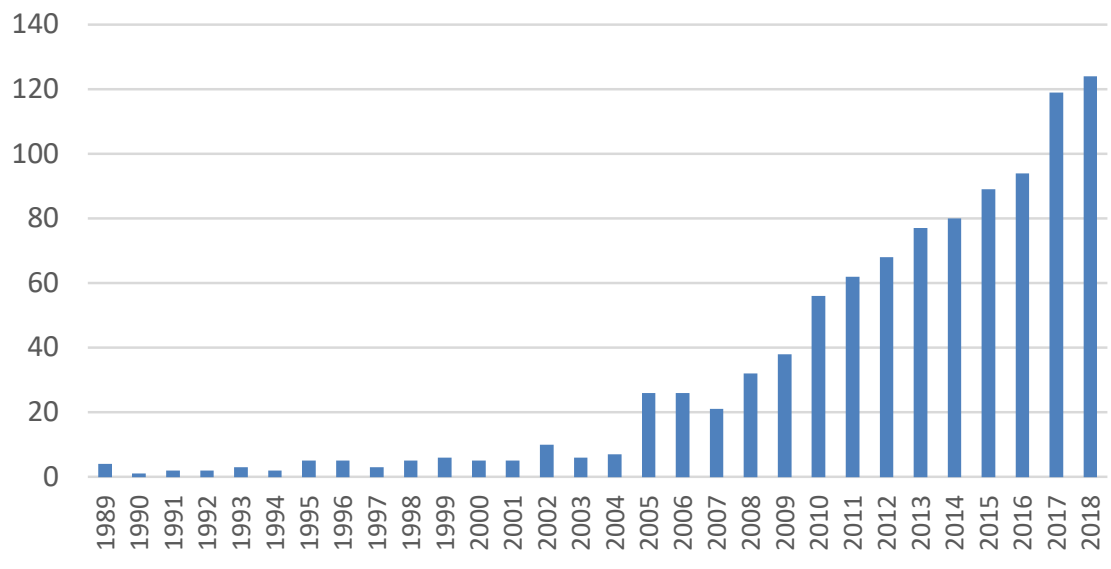

Figure 1. The number of publications including the key words “Comparative International Entrepreneurship" in Scopus in the years 1989-2018 Source: own study based on Scopus.

In the Scopus base in the years 1989-2018, 185 publications were recognized including the phrase 'Comparative International Entrepreneurship'. In the first years there were single papers on that. A visible increase in the studies took place after 2005. A great increase in the publications in this research area has been visible since 2009, and its dynamics in recent years indicates its great potential for future research. The most popular key words which were identified with the searched phrase were: international entrepreneurship, entrepreneurship, entrepreneur, international comparisons. The prevailing form of publications are scientific articles $(n=125)$, books $(n=16)$, conference materials $(n=18)$, chapters in monographs $(n=25)$, whose authors are usually researchers from the US, Great Britain and Canada.

The article by Jones, Coviello and Tang (2011) can be regarded a ground-breaking paper on comparative international entrepreneurship. The publication indicates research domains entering the area of research related to international entrepreneurship. Over the period of eight years, the article was cited over 400 times. Another popular paper is the work by Thomas and Mueller (2000) on the influence of culture of entrepreneurship in the comparative approach. An important publication on comparative international entrepreneurship, which is the first and so far the only review of the research into this (Systematic Review) is the paper by Terjesen, Hessels and Li (2013). The work based on the query of literature from the period 1989-2010 from 21 top scientific journals sumps up the output of international comparative research ordering it according to four levels: 1) individual entities, 2) firms micro, 3) industries - meso, 4) countries - macro. The research on the bases of individuals 
concerns the characteristics and definition of the properties of individuals - entrepreneurs: gender, education, social capital, psychological attributes, entrepreneurial orientation (Terjesen, Hessels, \& Li, 2013). Studies concerning firms are most numerous and concern internationalisation, comparisons of firms, business models, entrepreneurial orientation, resources and effects of entrepreneurship on the micro level (Terjesen, Hessels, \& Li, 2013). Comparative research on industries is, on the other hand, the lowest percentage of papers. It concerns small and medium-sized enterprises, enterprises of increased risk, the informal sector (Terjesen, Hessels, \& Li, 2013). One-fourth of comparative research on entrepreneurship concerns the macro-level. These are papers discussing the subject of the determinants of domestic entrepreneurship and its effects. Entrepreneurship is perceived as a stimulant of growth and economic development (Terjesen, Hessels, \& Li, 2013).

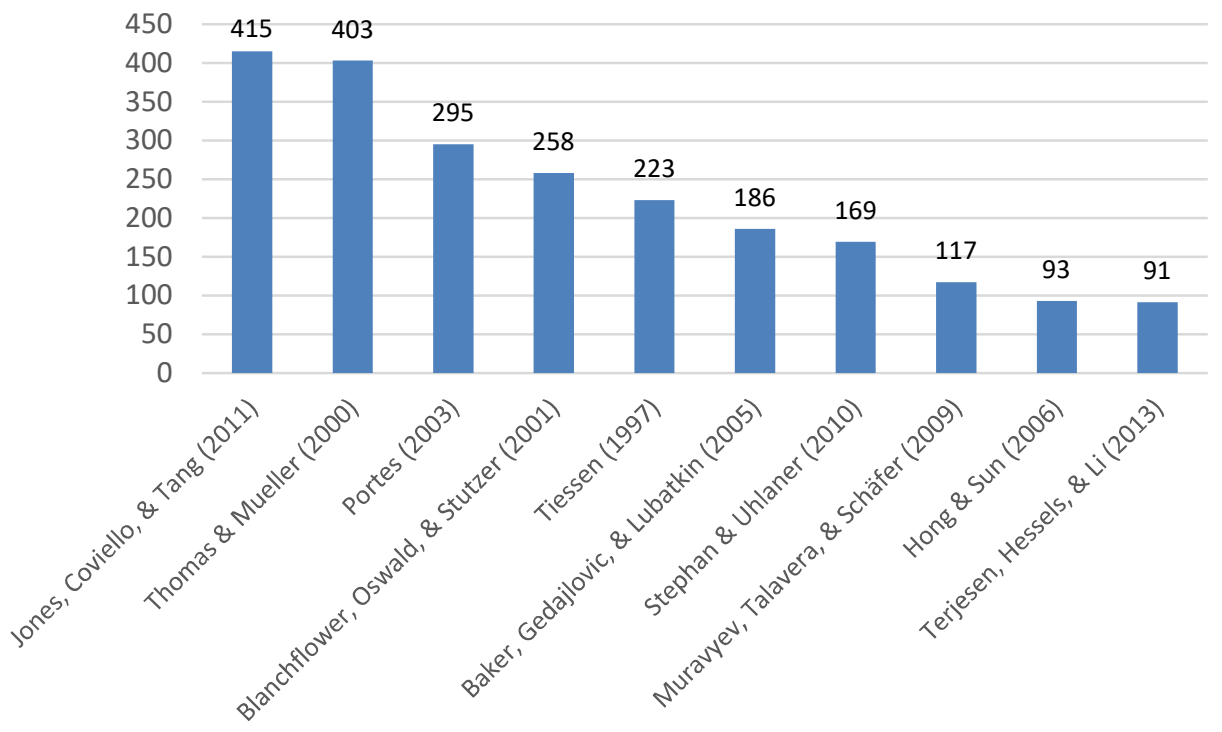

Figure 2. Most frequently cited publications on comparative international entrepreneurship in Scopus in the years 1989-2018 Source: own study based on Scopus.

The analysis of the content of publications on comparative international entrepreneurship allows to notice some issues which seem to be particularly important in the area of comparative research on international entrepreneurship. In the initial years of the interest in this domain, the problems of culture and institutional conditionings of entrepreneurship in the comparative approach were discussed. Based on the institutional theory, the creation and formation of entrepreneurship were analysed. The subjects are still being developed (Richet, 1993; Chang \& Kozul-Wright, 1994; Kshetri, 2009). Nowadays, research is undertaken into institutional, financial, human or logistical infrastructure in the context of entrepreneurship and mutual relationships between these categories (Manolova, Brush, Edelman, Robb, \& Welter, 2017). It is a very important issue to understand entrepreneurial capabilities, recognition and use of opportunities of different economies and societies. The re- 
search points to the feedback-type relation between the institutional environment and entrepreneurship. Particularly important is research into the influence of institutional conditionings on small and medium-sized enterprises (Acs, Morck, \& Yeung, 2001; Stephan \& Uhlaner, 2010). Similar research was conducted from the point of view of cultural conditionings (Holt, 1997; Tiessen, 1997; Thomas, Mueller, \& Jaeger, 2002; Lombardi, Lardo, Cuozzo, \& Treguattrini, 2017). The influence of different cultures on the level of entrepreneurship and various entrepreneurial qualities were verified (Thomas \& Mueller, 2000).

Proposition 2: The papers realised within international comparative research on entrepreneurship showed the co-dependence of institutional and cultural conditionings and entrepreneurship in different countries.

An important problem recognized in international comparative research is the domestic entrepreneurship measurement. There are more and more publications on the measurement of domestic entrepreneurship and its international comparisons, in which authors try to create authorial entrepreneurship measures on the macro-level. So far, the most popular measure created within works by the representatives of Bobson College and London Business School is Global Entrepreneurship Monitor (GEM). The report includes a great variety of aspects related to entrepreneurship in the international dimension: measuring entrepreneurial activity in countries, identifying factors determining the entrepreneurship level of economies (Àlvarez, Urbano, \& Amorós 2014). Another measure applied to determine entrepreneurship at a country level is the proposition of the World Bank - the World Bank Group Entrepreneurship Survey (WBGES). In the research the benchmark of the economic activity in the group of developed and developing countries is sought in order to build a database on the typology and characteristics of international business activity based on data obtained directly from institutions registering business activity in different countries (Ács, Desai, \& Klapper, 2008). An alternative approach to the measurement of the entrepreneurship of countries was proposed within the collaboration of the European Statistical Office (Eurostat) with the Organization for Economic Cooperation and Development (OECD) in the Entrepreneurship Indicator Programme (EIP) programme. As a result, a database was developed to conduct comparative research on entrepreneurship in three dimensions (Eurostat, 2018): 1) conditionings of entrepreneurship, 2) results of entrepreneurship, 3) effects of entrepreneurship. Attempts to operationalise domestic entrepreneurship for the needs of international comparative research can be also found in works by van Stel (2006), Ács, Szerb and Autio (2014).

Proposition 3: One of the key research problems recognized within comparative international entrepreneurship is the operationalisation of domestic entrepreneurship that is, at the macro-level.

Conducting research into the operationalisation of a country's entrepreneurship for the needs of international comparisons has a cognitive and utilitarian value. It can be a starting point to carry out in-depth research into changes, development, dynamics and causative factors of entrepreneurship of different countries, the identification of disproportions between economies and the sources of their occurrence. It can be also used to assess the effects of entrepreneurship of different countries. It concerns the recognition of the significance of entrepreneurship for economic growth, development and human welfare. Not only in the economic but also in the behavioural sense entrepreneurship is 
related to the search for and implementation of new forms of development and a change in the social status by active individuals, societies and nations (Klonowska - Matynia \& Palinkiewicz, 2013). Focus on the effects of entrepreneurship which are positive for economy, and the purposefulness of entrepreneurial activities can be seen in works of international institutions and organisations (OECD, 2008; 2017; European Commission, 2018). In the majority of studies, the positive impact of entrepreneurship on economic growth is confirmed (Audretsch, 2007; Baumol \& Strom, 2007; Ács, Audretsch, Braunerhjelm, \& Carlsson, 2009; Olaison \& Sorensen 2014). According to the research by Sternberg and Wnnekers (2005), the impact of entrepreneurship on economic development is evident and depends on the level of development of a given economy. It is also confirmed in other papers (Valliere \& Peterson, 2009; Ferreira, Fayolle, Fernandes, \& Raposo, 2017).

Proposition 4: Comparative international entrepreneurship in the context of the assessment of the effects of entrepreneurship has shown the relationship between the level of entrepreneurship of a country and its economic growth.

\section{DISCUSSION}

Based on the analysis of the content of papers created so far on comparative international entrepreneurship, we can claim that it is a very prospective research area with high potential for future research. The problem is not recognized properly and there are a lot of opportunities to conduct research in the stream of international entrepreneurship. Recently, a lot of pressure is put on the need to develop research concerning the Central and Eastern Europe region (Andersson, Evers, \& Kuivalainen, 2014; Terjesen, Hessels, \& Li, 2013; Perényi \& Losoncz, 2018). In fact, there are papers undertaking the problem of the influence of the political transformation in central and Eastern Europe on entrepreneurship (Richet, 1993) or on forms of business activity in post-socialist economies (Kshetri, 2009), but conducting research on entrepreneurial processes taking place in that region is still desirable.

There is a very clear space of scientific exploration in the area of international comparisons of cultural conditionings of entrepreneurship. Holt (2017) attempted to compare two contrasting societies in terms of culture in order to verify the impact of Chinese and American cultures on entrepreneurship. The research findings proved obvious differences but also some similarities of the studied societies. According to the author, cultural differences result from Confucian influences in China. On the other hand, similarities arise from the progressing globalisation. Similar findings are presented by Tiessen (1997) on the example of American and Japanese societies. Verification of the impact of culture on entrepreneurship may concern various areas. At present, the problem is still very important, especially comparative research may focus on associating culture with entrepreneurial processes, immigrant entrepreneurship and education for entrepreneurship (Lombardi, Lardo, Cuozzo, \& Treguattrini, 2017).

It is necessary to search further for an appropriate measure of a country's entrepreneurship for international comparisons. Empirical research often boils down to the selection of one representative entrepreneurship indicator, such as: the number of newly-established firms, the saturation with firms, survival of businesses, firms' growth dynamics, the percentage of the self-employed (Valdez \& Richardson, 2013; Canever \& Menezes, 2017; Dvouletý, 2017). There is a need to build a measure which would consider all dimensions of 
entrepreneurship. Among the presented aggregated measures, the most popular one is the GEM approach. It is based on institutional bases of entrepreneurship, which does not show the multidimensionality of the category which a country's entrepreneurship is. Institutions and the institutional environment are very important for entrepreneurship, but we cannot also skip the behavioural, economic, sociological and psychological approaches. GEM Monitor is too focused on the aspect of creating new businesses, leaving aside the assessment of the permanence of ventures (Audritsch, 2003; Hindle, 2010). In spite of those limitations, GEM indices have a substantial informative value. Research in this direction is worth continuing, which is necessary for the intensification of research into entrepreneurship in relation to other areas of socio-economic life. It is particularly important to recognize the impact of entrepreneurship on the condition of economy and inducing its economic growth. Declaratively, the European Commission (2018) indicates that economic growth in Europe and employment depend on the development of enterprises. Entrepreneurship stands for new firms, new markets and new opportunities. Encouragement for entrepreneurship, establishing firms, promotion of small and medium-sized enterprises are the key objectives of the EU activities. On the other hand, the World Bank (2013) regards innovations and entrepreneurship as the fundamental factors of a competitive and dynamic economy. Countries and regions characterised by innovativeness and entrepreneurship are characterised by higher productivity, which, as a result, leads to an increase in employment and then to economic growth and welfare of citizens. However, empirical research does not provide uniform results in this area, which may be an impulse for conducting in-depth research in this issue (Sternberg \& Wennekers, 2005; Valliere \& Peterson, 2009; van Stel, Thurik, Stam, \& Hartog, 2010; Ferreira, Fayolle, Fernandes, \& Raposo, 2017).

Other research problems which may be recommended for further research in the area of international entrepreneurship in the comparative approach are: entrepreneurship of women, entrepreneurial orientation, social entrepreneurship and comparison of entrepreneurial internationalisation.

\section{CONCLUSIONS}

International comparisons of entrepreneurship are one of three research domains of international entrepreneurship. It is a relatively new research area, which has been developing since 1980s. Comparative research within international entrepreneurship is not, however, popularised in empirical research, and entrepreneurship itself is first of all associated with internationalisation. Comparative international entrepreneurship is part of the research into international entrepreneurship, which arises from its theoretical bases. For a few years, growing interest in international entrepreneurship in the comparative approach has been observed, which can be understood as a kind of a future, emerging trend of research. Based on the analysis of the content of existing papers we can claim that this direction of research will be developed and has a lot of potential. We can identify a few important problems for empirical verification, which concern institutional and cultural conditionings of entrepreneurship, operationalisation of entrepreneurship, and the assessment of the effects of entrepreneurship for economic growth and development.

This article can be treated as an initial study on the comparative research in international entrepreneurship. However, it has some limitations, which can be seen at the same time as recommendations for future research. Undoubtedly, there is a need to 
conduct in-depth theoretical and empirical research in this stream. An important limitation in this article is the lack of application of more advanced research tools for the analysis of the content. It is recommended to apply appropriate software dedicated strictly to bibliometric analysis that allows for in-depth analysis. On this basis the bibliographic relations recognition would be possible. In addition, it is worth to take into account a larger range of available databases. The limitation of the study may also seem to be the recognition of only research trends without indicating the links between them, which should definitely be examined in the future.

Theoretical studies are desired, which would verify the scientific identity of international entrepreneurship, thus, international comparative research into entrepreneurship. What also seems to be important are systematic papers of literature review. To date, there is practically only one such a paper on comparative international entrepreneurship. Also empirical research should be developed. There are a lot of possibilities to conduct comparative research of various dimensions, types and conditionings of entrepreneurship in the international scale. Recommended research contributes to the development of the scientific discipline and can be used in practice both at the micro-level by entrepreneurs and managers, and at the macro-level, by economic and political decision makers.

\section{REFERENCES}

Ács, Z.J., Morck, R.K., \& Yeung, B.(2001). Entrepreneurship, globalization, and public policy. Journal of International Management, 7(3), 235-251.

Ács, Z.J., Desai, S., \& Klapper, L.F. (2008) What does 'entrepreneurship' data really show? Small Business Economics, 31(3), 265-281.

Ács, Z.J., Audretsch, D.B., Braunerhjelm, P., \& Carlsson, B. (2009). The knowledge spillover theory of entrepreneurship. Small Business Economics, 32(1), 15-30.

Ács, Z.J., Autio, E., \& Szerb, L. (2014). National Systems of Entrepreneurship: Measurement issues and policy implications, Research Policy, 43(3), 476-494.

Allen, I. (2016). International Entrepreneurship Theory: Past, Present and Way Forward. Entrepreneurial Business and Economics Review, 4(4), 93-203. https://doi.org/10.15678/EBER.2016.040406

Álvarez, C., Amorós, J.E., \& Urbano, D. (2014). Regulations and entrepreneurship: Evidence from developed and Developing countries. Innovar, 24, Edición Especial, 81-89.

Andersson, S., Evers, N., \& Kuivalainen, O. (2014). International new ventures: rapid internationalization across different industry contexts. European Business Review, 26(5), 390-405.

Audretsch, Z.J. (2003). Entrepreneurship A survey of the literature. Enterprise Papers, 14. Retrieved from: http://ec.europa.eu/DocsRoom/documents/2977/attachments/1/translations/en/renditions/pdf on January 24, 2019

Audretsch, D.B. (2007). Entrepreneurship capital and economic growth. Oxford Review of Economic Policy, 23(1), 63-78. https://doi.org/10.1093/oxrep/grm001

Baumol, W.J., \& Strom, R.J. (2007). Entrepreneurship and economic growth. Strategic Entrepreneurship Journal, 1, 233-237.

Autio, E. (2018). Creative Tension: The Significance of Ben Oviatt's and Patricia McDougall's Article 'Toward a Theory of International New Ventures'. In R. Reuber (Ed.), International Entrepreneurship. The Pursuit of Opportunities across National Borders (pp. 59-81). Gewerbestrasse: Palgrave Macillan. 
Beynon, M.M., Jones, P., \& Pickernell, D. (2018). Country-based comparison analysis using fsQCA investigating entrepreneurial attitudes and activity. Journal of Business Research, 69(4), 1271-1276.

Brouthers, K.D., \& Nakos, G. (2004). SME entry mode choice and performance: A transaction cost perspective. Entrepreneurship Theory \& Practice, 28, 229-247.

Canever, G., \& Menezes, M. (2017). New firm formation, spatial trends and economic performance: evidences from Rio Grande do Sul, Brazil. Revista Brasileira De Economia De Empresesas, 17(1), 39-53.

Chang, H.J., \& Kozul-Wright, R. (1994). Organising Development: Comparing the National Systems of Entrepreneurship in Sweden and South Korea. The Journal of Development Studies, 30(4), 859-891.

Coviello, N.E., McDougall, P.P., \& Oviatt, B.M. (2011). The emergence, advance and future of international entrepreneurship research - An introduction to the special forum. Journal of Business Venturing, 26(6), 625-631.

Daszkiewicz, N. (2014). Przedsiębiorczość międzynarodowa jako nowy obszar badań w teorii internacjonalizacji. In A. Budnikowski \& A. Kuźniar (Eds.), Nowe Procesy w Gospodarcze Światowej: Wnioski dla Polski (pp. 207-220). Warszawa: Oficyna Wydawnicza Szkoły Głównej Handlowej w Warszawie.

Dvouletý O. (2017). Determinants of Nordic entrepreneurship. Journal of Small Business and Enterprise Development, 24(1), 12-33.

Etemad, H. (2018). The essence of entrepreneurial internationalization: Managing the dynamic complexity of interactive relationship and reflective adaptations. Journal o International Entre-preneurship, 16(3), 325-337. https://doi.org/10.1007/s10843-018-0237-4

European Commission (2018). The Entrepreneurship 2020 Action Plan (Analytical Report). Retrieved from https://ec.europa.eu/growth/smes/promoting-entrepreneurship/actionplan_en on February 10, 2019.

Eurostat (2018). Entrepreneurship indicators. Retrieved from https://ec.europa.eu/eurostat/web/structural-busoniness-statistics/entrepreneurship/indicators on February 10, 2019.

Ferreira, J.J., Fayolle, A., Fernandes, C., \& Raposo, M. (2017). Effects of Schumpeterian and Kirznerian entrepreneurship on economic growth: panel data evidence. Entrepreneurship \& Regional Development, 29(1-2), 27-50.

Hindle, K. (2010). How community context affects entrepreneurial process: A diagnostic framework. Entrepreneurship \& Regional Development, 9, 599-647.

Hofman-Kohlmeyer, M. (2018). Przedsiębiorczość międzynarodowa w świetle badań naukowych przegląd literatury. Studia Ekonomiczne, 352, 100-110.

Holt, D.H. (1997). A comparative study of values among Chinese and U.S. entrepreneurs: Pragmatic convergence between contrasting cultures. Journal of Business Venturing, 12(6), 483-505.

Jones, M.V., \& Coviello, N.E. (2004). Methodological issues in international entrepreneurship research. Journal of Business Venturing, 19, 485-508.

Keupp, M.M., \& Gassman, O. (2009). The Past and the Future of International Entrepreneurship: A Review and Suggestions for Developing the Field. Journal of Management, 35(3), 600-633.

Klonowska-Matynia, M., \& Palinkiewicz, J. (2013). Przedsiębiorczość w teorii ekonomicznej. Zeszyty Naukowe Wydziału Nauk Ekonomicznych Politechniki Koszalińskiej, 17, 29-40.

Knight, G.A., \& Cavusgil, S.T. (2004). Innovation, organizational capabilities, and the born global firm. Journal of International Business Studies, 35, 124-141, https://doi.org/10.1057/palgrave.jibs. 8400071

Kraśnicka, T. (2012). Przedsiębiorczość międzynarodowa jako odrębny obszar badań. In T. Kraśnicka (Ed.), Przedsiębiorczość międzynarodowa. Aspekty teoretyczne i praktyczne (pp. 11-19). Katowice: Wydawnictwo AE w Katowicach. 
Kshetri, N. (2009). Entrepreneurship in post-socialist economies: A typology and institutional contexts for market entrepreneurship. Journal of International Entrepreneurship, 7(3), 236-259.

Lombardi, R., Lardo, A., Cuozzo, B., \& Trequattrini, R. (2017). Emerging trends in entrepreneurial universities within Mediterranean regions: An international comparison. EuroMed Journal of Business, 12(2), 130-145.

Manolova, T.S., Brush, C.G., Edelman, L.F., Robb, A., \& Welter, F. (2017). Entrepreneurial ecosystems and growth of women's entrepreneurship: A comparative analysis. Cheltenham: Edward Elgar Publishing Ltd.

McDougall, P.P. (1989). International versus domestic entrepreneurship: New venture strategic behavior and industry structure. Journal of Business Venturing, 4, 387-400.

McDougall, P.P., \& Oviatt, B.M. (1994). Toward a theory of international new ventures. Journal of International Business Studies, 25(1), 45-64.

McDougall, P.P., \& Oviatt, B.M. (2000). International Entrepreneurship: The Intersection of Two Research Paths. The Academy of Management Journal, 43(5), 902-906.

McDougall, P.P., \& Oviatt, B.M. (2003). Some Fundamental Issues in International Entrepreneur-ship. Entrepreneurship Theory \& Practice, 8, 1-27. https://doi=10.1.1.210.861\&rep=rep1\&type=pdf

McDougall, P.P., \& Oviatt, B.M. (2005). Defining international entrepreneurship and modeling the Speed of Internationalization. Entrepreneurship Theory and Practice, 29(5), 537-554. https://doi.org/10.1111/j.1540-6520.2005.00097.x

OECD. (2008). Measuring Entrepreneurship: A Digest of Indicators. Paris: OECD Publishing.

OECD. (2017). Entrepreneurship at Glance 2017. Paris: OECD Publishing.

Olaison, L., \& Sørensen, B.M. (2014). The object of entrepreneurship: failure, fiasco, fraud. International Journal of Entrepreneurial Behaviour \& Research, 20(2), 193-211.

Perényi, A., \& Losoncz, M. (2018). A Systematic Review of International Entrepreneurship Special Issue Articles. Sustainability, 10(10), 3476, 1-26. https://doi:10.3390/su10103476

Richet, X. (1993). Transition Towards the Market in Eastern Europe; Privatisation, Industrial Restructuring and Entrepreneurship. Communist Economies and Economic Transformation, 5(2), 229-243.

Stephan, U., \& Uhlaner, L.M. (2010). Performance - based vs socially supportive culture: A cross national study of descriptive norms and entrepreneurship. Journal of International Business Studies, 41(8), 1347-1364.

Sternberg, R., \& Wennekers, S. (2005). Determinants and Effects of New Business Creation Using Global Entrepreneurship Monitor Data. Small Business Economics, 24, 193-203. http://dx.doi.org/10.1007/s11187-005-1974-z

Terjesen, S., Hessels, J., \& Li, D. (2013). Comparative international entrepreneurship: A review and research agenda. Journal of Management, 42, 299-234. http://doi.org/10.1177/0149206313486259

Thomas, A.S., \& Mueller, S.L. (2000). A case for comparative entrepreneurship: Assessing the relevance of culture. Journal of International Business Studies, 31(2), 287-301.

Thomas, A.S., Mueller, S.L., \& Jaeger, A.M. (2002). National entrepreneurial potential: The role of culture, economic development, and political history. Advances in Comparative International Management, 14, 221-257.

Tiessen, J.H. (1997). Individualism, collectivism, and entrepreneurship: A framework for international comparative research. Journal of Business Venturing, 12(5), 367-384.

Valdez, M., \& Richardson, E.J. (2013). Institutional Determinants of Macro-Level Entrepreneurship. Entrepreneurship Theory and Practice, 37(5), 1149-1175. 
Valliere, D., \& Peterson, R. (2009). Entrepreneurship and economic growth: Evidence from emerging and developed countries. Entrepreneurship \& Regional Development, 21(5-6), 459-480.

Van Stel, A., Carree, M., \& Thurik, A.R. (2005). The effect of entrepreneurial activity on national economic growth. Small Business Economics, 24(3), 311-321.

Van Stel, A. (2006). Empirical Analysis of Entrepreneurship and Economic Growth. Berlin: Springer.

Van Stel, A., Thurik, R., Stam, \& Hartog, C. (2010). Ambitious entrepreneurship, high growth firms and macroeconomic growth (EIM Research Reports). Retrieved from http://citeseerx.ist.psu.edu/viewdoc/download?doi=10.1.1.502.6357\& rep=rep1\&type=pdf on January 10, 2019.

Wach, K. (2018). Theoretical foundations for international entrepreneurship. In K. Wach (Ed.), Internationalization of Firms in the Perspective of International Entrepreneurship (pp. 6396). Warszawa: PWN.

World Bank. (2013). World Bank Group Support for Innovation and Entrepreneurship (An Independent Evaluation Report). Retrieved from http://ieg.worldbankgroup.org/sites/default/files/Data/Evaluation/files/innovation_eval.pdf on November 2, 2019.

Zucchella, A., \& Magniani, G. (2016). Entrepreneurship. Theoretical Foundations and Practices. 2nd edition. New York: Palgrave Macmillan.

\section{Author}

\section{Agnieszka Głodowska}

Assistant Professor in the Department of International Trade, PhD in economics, author of the publications on international business and international entrepreneurship, member of editorial boards of 'Entrepreneurial Business and Economics Review' (Scopus, ESCI WoS), 'International Journal of Managerial Studies and Research' (USA), 'International Entrepreneurship' (Poland). Research interests: international entrepreneurship, finance and risk in international business.

Correspondence to: Dr Agnieszka Głodowska, Cracow University of Economics, ul. Rakowicka 27, 31-510 Kraków, Poland, e-mail: glodowsa@uek.krakow.pl

ORCID (1) http://orcid.org/0000-0002-5317-8625

\section{Acknowledgements and Financial Disclosure}

This publication is financed from the funds allocated to the Faculty of Economics and International Relations of the Cracow University of Economics in the framework of grants for maintaining research potential.

\section{Copyright and License}

This article is published under the terms of the Creative Commons

Attribution - NoDerivs (CC BY-ND 4.0) License

http://creativecommons.org/licenses/by-nd/4.0/

Published by the Centre for Strategic and International Entrepreneurship - Krakow, Poland 